\title{
Defamiliarization and the Creation of El Greco's Mysterious Atmosphere*
}

\author{
Yi Zhang \\ Institute of Digital Art \\ Nanjing Vocational College of Information Technology \\ Nanjing, China
}

\begin{abstract}
The poet who was a friend of El Greco once told Greco in his letter: "Eccentricities will be extolled in the future", which become true 300 years later. Greco has undoubtedly been known as a great painter. The strong mysticism in his paintings and his aesthetic philosophy, even today, are still respected by modern painters. He became the "modern generation and Cezanne's contemporaries". [1] What methods did Greco use to make his paintings full of mysticism? This paper, starting from the creative means of "art defamiliarization" and combining with its cultural and religious background, aims to make an objective and reasonable analysis about the specific methods of its mysterious atmosphere, in order to prepare for personal artistic creation in the future.
\end{abstract}

Keywords-defamiliarization; content; form; language; symbolism

\section{INTRODUCTION}

Defamiliarization is the representative theory of Russian formalism. The figure of speech of "defamiliarization", adds mysterious aesthetic feeling into literary works. In fact, not only in literature, in painting, defamiliarization is also an effective processing method in creation of the expressive object. It can make the familiar objects become strange and distant. This strange sense of distance makes the process of appreciation novel and unique. So the audiences can feel a mysterious atmosphere in paintings.

Defamiliarization in painting contains two steps: 1 . defamiliarization of the artistic content; 2 . defamiliarization of artistic form language.

\section{DEFAMILIARIZATION OF THE ARTISTIC CONTENT}

Defamiliarization of artistic content is closely related to symbolism. "Symbol is mysticism", which means if the artist transformed direct content into implied and metaphorized, the aesthetic psychological distance will be brought. Meanwhile, if the artist chose appropriate symbols to express this feeling of distance, the mysterious atmosphere will be created. Symbolism and metaphor are the frequently used techniques in El Greco's paintings. There are also lots of

*Sponsorship of Jiangsu Overseas Visiting Scholar Program for University Prominent Young \& Middle-aged Teachers and Presidents. symbolic sign in El Greco's form language system. All of them play a key role in building mysterious atmosphere.

\section{A. Light and Visual Symbol}

In order to build a fantastic dream world, El Greco used light and color to form the contract point in his painting. It reflects a very complicated process in his spiritual world, which contains mysterious power. It is not only an expression of El Greco's philosophy view, but also a release of inner feelings. Take the "light" for example, it originates from religion, and play extraordinary part in El Greco"s symbolic language system.

From the point of subject matter, the painting of light itself has strong religious metaphors and hints, because Jesus claims to be light of the world in John 8:12. In Isaiah 35:5"Then the eyes of the blind shall be opened, and the ears of the deaf shall be unstopped." In El Greco "s three extremely similar works which were named" Christ Healing the Blind", we can see "light" was quoted as a sign and symbol. The blind means that they cannot feel the light and cannot be inspired. The process of Christ's healing is not just to cure, it represented the opening of human senses and wisdom, the acceptance of God's call. In Matthew 20:27-34, the Christ cured two blind people. "Lord," they answered, "we want our sight". They want the true light that can illuminate the world, to open and light their eyes. Then they can see the beauty of these creations. They will admire and praise the wisdom and power of their creators." Henceforth, spiritually illuminated and grateful for such a remarkable benefit, they, together with the others, could follow Christ, not just physically with their feet, but also in imitation of his virtue. The story is a literal notation that can resonate highly with the audience, and it is also the symbolic visual sign that can "bezauberung" the emotional "consciousness" of creators and viewers.

"Bezauberung" is a German word. "Bezauberung" consciousness, raised by German Romantic poet, Christian master Novalis, refers to "a process of artificially stimulating beliefs".[2] The artists may use all kinds of artistic language to release their fantasies and passions in order to create a new spiritual world. And this world can also make the viewer infatuated. There are 3 ways of "bezauberung" consciousness: 
- "Bezauberung" the viewers, partially assimilate others, and let the viewers see, believe and perceive in the way he expects. In fact, it is also an empathy process.

- "Bezauberung" the artist himself, fantasying a nonego and make himself intoxicated. "His magic is like an alien phenomenon of autonomy."[3]

- "Bezauberung" the objects, which means using the symbolic object to express.

By using three ways of "Bezauberung", El Greco transformed literal rotation into symbolic visual sign through his painting. "Light" which was an invitation for all, became a media of God. When appreciating the paintings, the viewers, like the healed blind in the picture, were invited by Christ, accepted God's grace, and achieved spiritual healing. Meanwhile, the theme can also appear again in "some pious texts." "Since these three paintings of Christ healing the blind were possibly for private use, they can be attached to the relevant prayer manuals, providing reference notes on the symbolic significance of vision and blindness."[4] Finally, they attracted "Worshipers directly participate in visual theology," and appeared in other articles. They echoed Greco's works and formed "intertextuality", which referred to each other.

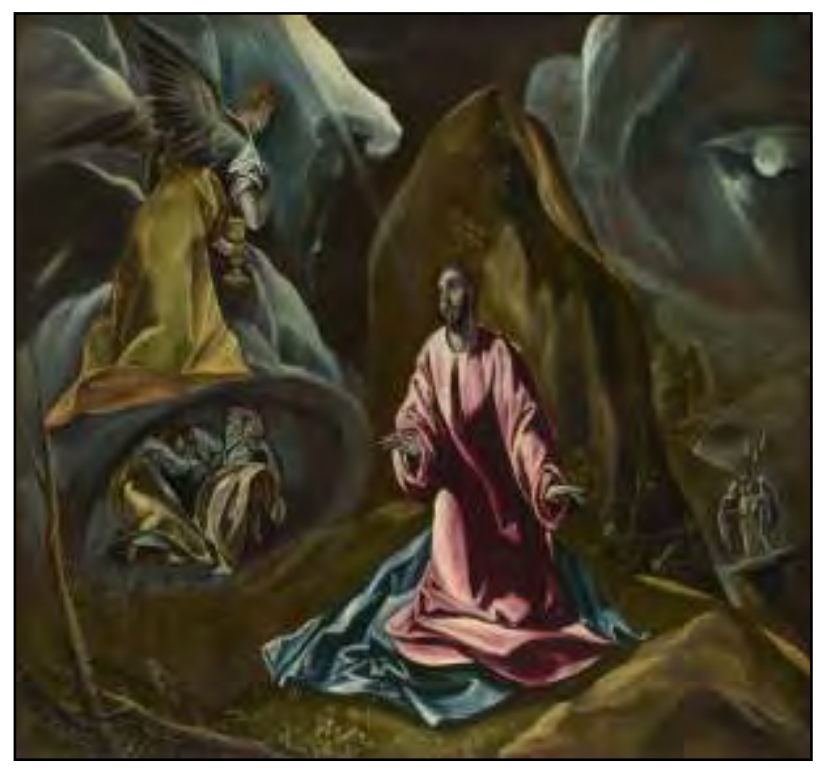

Fig. 1. Agony in the Garden.

\section{B. "Space" and Visual Symbol}

Compared with "light", the clear symbolic characteristics, "space" was not so obvious. But in El Greco"s paintings, "space" was also an important metaphor and symbol. In some of El Greco"s paintings, featuring with numerous figures and complex narrative story, "space" is not a description and representation of naturalistic space, but a symbol of mental space. Take "Agony in the Garden" ("Fig. 1") for example, according to Luck22:43-44, after the final dinner, Christ accompanied Peter, John and Jim, the three apostles to pray. He felt overwhelming sadness and anguish, and said "My Father, if it is possible, let this cup pass me by. Nevertheless, let it be as you, not I, would have it. "Then, a little while later, He said, "If this cup cannot pass by, but I must drink it, your will be done!" He said this prayer three times, checking on the three apostles between each prayer and finding them asleep. An angel came from heaven to strengthen him. During his agony as he prayed, his sweat was as it were great drops of blood falling down upon the ground".

In El Greco"s works, the figures were endowed with noble spirit, however, it lost the heroic nature of Tintoretto "es works. The fate of figures in El Greco"s works was blindly obeyed to the highest mysterious power. Therefore, in describing this scene, the painter did not create a unified depth space for simulating naturalism. But he used clouds, stones, paths and so on, to segment the picture, and to form many different regional spiritual "space". In this picture, the upper left was an angle from heaven, expressing the sacred spiritual space of the God. The disciples at the lower left are expressing weak spiritual space. In the middle of the painting, Jesus suffered from death and torture, but remained firm, expressing faith and loyalty to the God. This is the spiritual space of the rescuer and pioneer. As for the group on the right, representing the spiritual space of the publices confused and evil.

The "space" is different from the light, which is not a diagram of a text, nor a text symbol. It was a symbolic visual symbol, which contained profound implications of the times. "Art is the container of time spirit."[5] The behaviors of artistic creation were impossible to be separated from the background of the times. At that time, the northern part of Europe was suffering spiritual crisis brought by religious reform, which set off the trend of collapse of spiritual belief. "Disillusionment led people to doubt the value of any theory or moral laws based on reason, and made people clearly aware of the limitations of human perception and the relativity of knowledge."[6] In Spain, Gothic is still popular, as well as mysticism. Unlike the pursuit of induction, realistic description of the natural environment, Spanish painters advocate deduction, pay attention to spiritual feelings, hoping to awaken people's inner godliness. Therefore, they chose the salvation of Christ as an eternal theme. To seek spiritual transmission with meditation and ecstasy is the direction of Greco's pursuit. "Space" was a reflection of the mental state of various people in reality, and also a reflection on the viewer. It's also the cultivation of the viewers. It is hoped that through enlightenment, their spiritual space can ascend from this world to sacred heaven. Therefore, "space" not only becomes the symbol to participate in shaping the unique character of his works, but also is the spiritual source of Greco's creation. The similar expression was also shown in El Greco"s other works such as "The Opening of the Fifth Seal of the Apocalypse", "The Burial of the Count of Orgaz", "Praise of the holy name" and so on. 


\section{DEFAMILIARIZATION OF ARTISTIC LANGUAGE}

Another important aspect of art defamiliarization is the defamiliarization of artistic form language. In some way, people in the process of appreciation, often do "not through the content to see the form, but through the form to see the content."(Viktor Shklovsky, 1893-1984) And Susan Sontag, in her "Against Interpretation and Other Essays", also puts forward the idea that "the overemphasis on content leads to the arrogance of interpretation, and that a broader and more thorough description of the form will eliminate this arrogance". Similarly, Michael Fried (1939- ) argues in "Art and Objecthood" that only "formal" criticism can show a "compelling value distinction". At the same time, only formal criticism can rationally control intuition.

From the time of ancient Greece, the western art language is closely related to the study and imitation of nature. Describing an artistic environment similar to nature obviously does not make the viewer feel strange, and undoubtedly does not create a mysterious atmosphere in the picture. Therefore, based on backward reasoning, the antinaturalism expression is undoubtedly the best way of defamiliarization. This way for Greco is to learn from Byzantine style.

Greco's life can be roughly divided into four periods: 1.From birth to 1566, he received the training of Byzantine style icons art in Crete, Greece. 2. In 1567, he came to Venice to study in Titian's studio. The color of Venice painting school has far-reaching influence on him. Dintoretto's elongated portrait, unconventional perspective, and uncertain light all give him great inspiration. 3. In 1570, He came to Rome. Despite Michelangelo's profound influence, he maintained that Michelangelo's work did not inspire religious fanaticism. So it's not noble enough.4. In 1577, he came to Spain and settled in Toledo, where he finally realized his pursuit and created immortal works that inspired religious exultation and intoxication in the artistic language of "defamiliarization".

\section{A. The Defamiliarization of Light and Color}

"Light is the almsgiver of all things..." [7] Light creates atmosphere and emotion. It is an important means of expression for the atmosphere in the picture.

"Don't let the light of nature affect the light in my heart," [8] Greco once drew the curtain all day. In his artistic mature period, light of his painting does not simulate nature, showing a tendency to get rid of the material and physical sense of the object. In order to highlight the mysterious effect, the light in the picture lacks a unified source. The figures in the light show a strong chiaroscuro. The subtle middle tones of the figures are deliberately reduced, coupled with exaggerated and distorted gestures, resulting in the mysterious "ecstasy" of Spanish religion.

Taking "The Opening of the Fifth Seal of the Apocalypse" ("Fig.2") as an example, there are many light sources on the screen.

- Saint John in the foreground: Light is shot from the top right side.
- Four people under the Yellow veil in the background: Light enters from above the center of their position.

- Three people under the green veil in the background: Light source is complex. The left figure is illuminated by the upper left light. The right man and the middle figure, the light comes from the center of their position.

At the same time, whatever light he used in the foreground, El Greco used the effect of back-projection in the background. In a large number of paintings, the painting methods of the background are almost patterned, for example the curly clouds. And the light came out of the clouds, and it seemed that there was light behind it. This is quite different from natural light. This effect is very similar to the bright golden background in Byzantine paintings, symbolizing the holiness and glory of Christ.

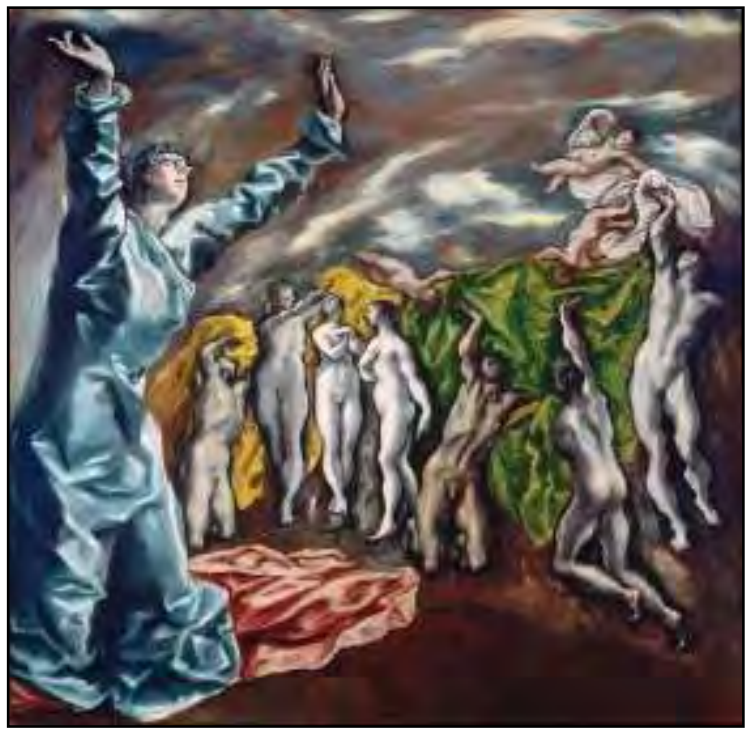

Fig. 2. The Opening of the Fifth Seal of the Apocalypse.

The color used in Greco's artistic mature period is extreme. The dark-value colors, such as black, brown or plain blue were strongly contrasted with bright high-purity, high- value colors, such as red, yellow, and white. And cold colors, such as green, blue, and lemon yellow, and warm colors, such as bright red and orange formed a great contrast between each other. They were unified by the black shadow and the border area, and were very strange and fantastic.

\section{B. The Defamiliarization of Space}

The space here is different from the "spiritual space" mentioned above. It refers to the area composed of the solid image and the blank image arranged in the composition. The arrangement of inner space will be formed along with the image and visual track. At that time, geometry and optics had been greatly developed, and perspective had evolved into a mature operating system. Science has been integrated into artistic creation. Especially the naturalistic space created in the picture by the focus perspective method had become the conventional formal language adopted by the painters at that 
time. Artists could create a precise, logical and rational space in a picture, and can objectively paint nature world.

And the sense of distance and space is actually caused by various factors such as the size and location of different images. But in Greco's painting, the factors were abnormal. Greco was obviously not interested in creating naturalistic spaces in the picture. He cared about the "exciting" religious expression. His mature period paintings draw lessons from the Byzantine art in painting on the two-dimensional plane. For example, "Christ on the Cross," the hills were not depicted by size and distance. The dark clouds behind Jesus with a bright light just above Christ's head, blocked up the space of the picture, echoed the gesture of Christ's open arms, and drew the audience's attention to the exaggerated movements. Another example is "The Burial of the Count of Orgaz" ("Fig.3"). In the background, crowded with nobles and guests who were in black, not only ranked horizontally, but each figure was almost the same size.

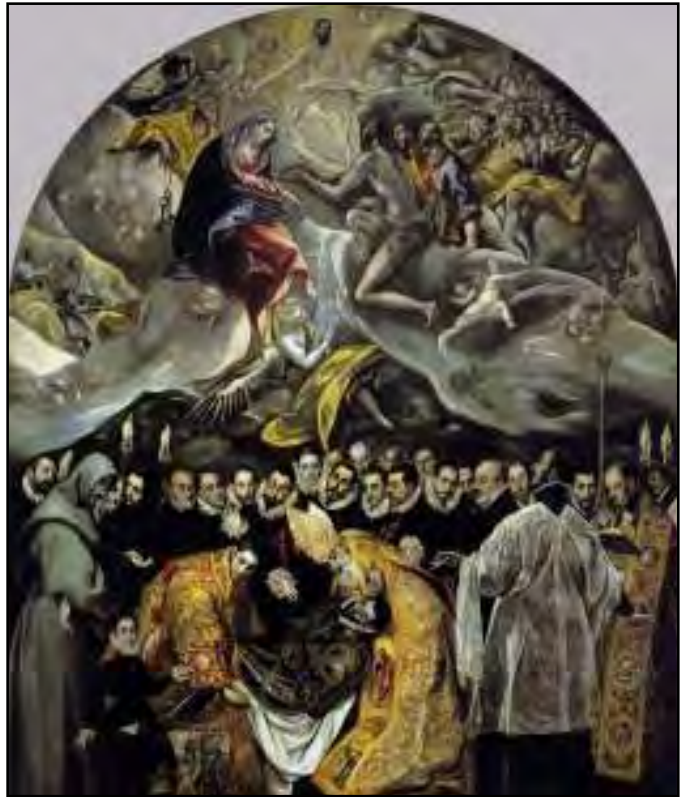

Fig. 3. The Burial of the Count of Orgaz.

The image of Jesus above was small, and the Virgin and Saint John are bigger... These abnormal ways of expression make the picture lack of unified depth space. At the same time, he used clouds and other props to form a variety of spaces, but each part presents an opposite situation, weakening the coordination of the overall space in the painting. It brought a strong sense of strangeness, and then stimulated a sense of mystery.

\section{The Defamiliarization of Composition}

In Greco's painting, the composition was different from the symmetrical pattern at that time, and there was no absolute center. Meanwhile, he used the diagonal structure, showing "V" and "X" type, and even more complex radiation type. For example," Apostles St. Peter and St. Paul" ("Fig. 4"), "Christ on the Cross"("Fig.5"), and "St. Andrew and St. Francis" ("Fig.6"), all have multiple explicit and implicit "V" and "X" structures. These structures were formed by figures' posture, clothing patterns, or even the clouds. The vertex of the V-shaped structure contains tremendous power to make the picture extraordinary momentum, while the X-shaped structure brings two groups of conflicting forces to the picture. Surprisingly, the center of $X$ was often located in the middle, and its shape was more regular, but it still forms a very strong visual impact. The reason was that there were multiple sets of repeating $\mathrm{V}$ or $\mathrm{X}$ structures in the same picture. Repetition is like "one sigh and three chants" in Chinese poetry, which will enhance the sense of conflict. It is quite different from the conventional realistic structure, forming a strong sense of strangeness and creating a very strong atmosphere of mystery.

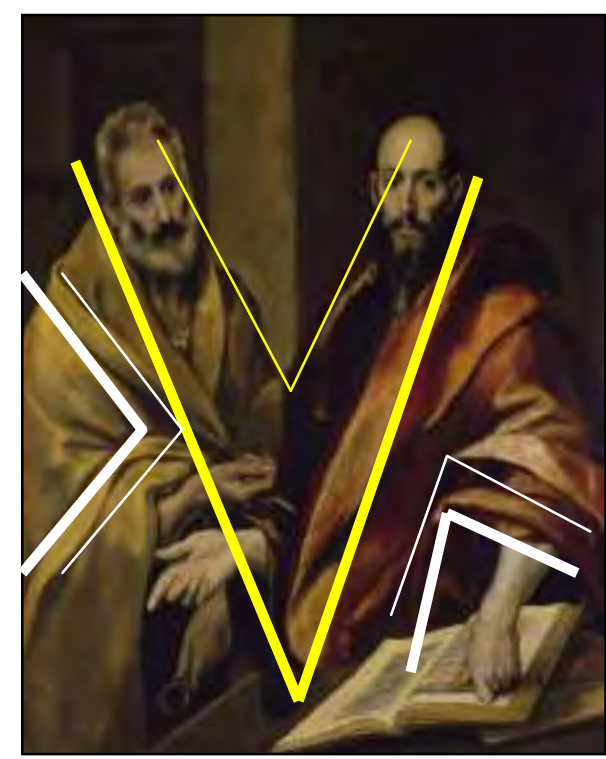

Fig. 4. Apostles St. Peter and St. Paul.

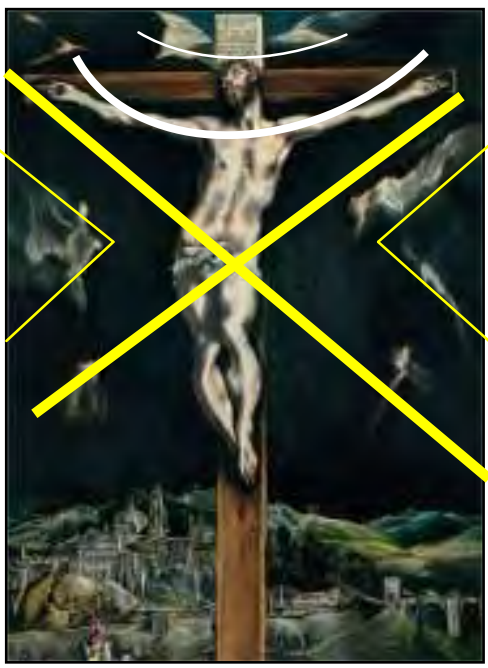

Fig. 5. Christ on the Cross. 


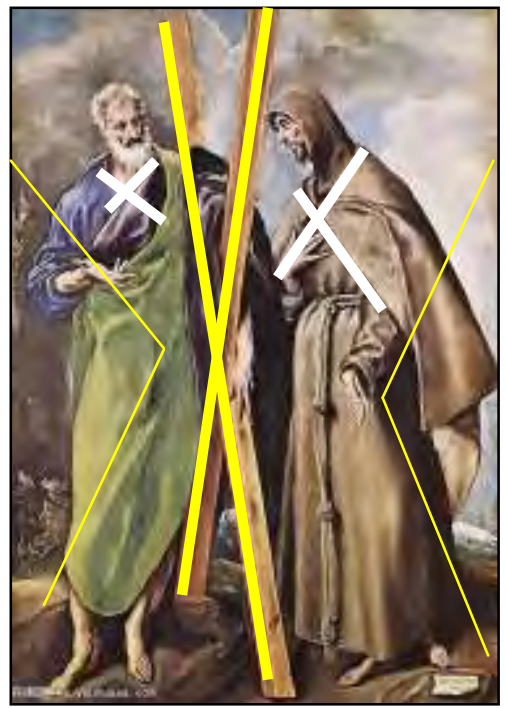

Fig. 6. St. Andrew and St. Francis.

\section{The Defamiliarization of Figure Modeling}

At that time, people believed that elegant style could only be acquired by gifted people. It was a right way to choose the patterns created by the greatest masters. Therefore, the painters often copied the works of their predecessors, regardless of whether they were compatible with the theme. This could explain why there were several figures in Greco's works that resemble those created by Michelangelo. "Creating in Michelangelo's way means maximizing the use of the limbs, which could lead us into the realm of multiple rotations and twists." The gestures of these human bodies were often unnatural, sometimes not even meaningful, just to meet the artist's needs for the creation of the picture, became a part of the schematization. At the same time, the proportion of the figures was abnormally "slender". And even in the same painting, a large number of figures were in different proportions, different sizes. It lacked a reasonable perspective.

In addition, on the one hand, Greco simplified the outline, on the other hand, he often used broad black lines or shadows to form outline. The black lines then distinctly separated the figures from the background, highlighting them as cameos on a "flat" background. These black lines reminded people of the colorful paintings on windows of Gothic cathedral. Such lines belonged to the twodimensional decorative style, and were not compatible with naturalistic three-dimensional figures. Therefore, this is a typical mean of defamiliarization, which can strongly stimulate the audience's feelings, help to promote the formation of a mysterious atmosphere.

\section{CONCLUSION}

As Dvorak said, there were two tendencies in art in the late sixteenth Century. "One tends to be realistic and inductive, and to achieve one's goals through two ways: one was to observe the environment carefully, and the other was to use the psychological conditions of individuals and societies that control the environment... The second was the tendency to deduce, his inspiration comes from the feeling of the world, that this feeling was the source of all noble and eternal things..."Undoubtedly, Greco belongs to the second kind. With his own subjective will and imagination, he had successfully created a mysterious spiritual world by displaying irrational free rhythm and defamiliarizing artistic content and artistic language.

\section{REFERENCES}

[1] Zhu Qi, "The runion and pursuit of Cezanne and his senior master,'Hundred Schooles in Art, China, vol 3, p231, 2008

[2] Liu Xiaofeng, "Novalis:Revolution und Religion in der Hymnen an die Nacht", Huaxia Publishing House, Beijing, p. 137, 2007

[3] Liu Xiaofeng," "Poetic philosophy", Shandong Publishing House of Literature and Art, Jinan, p. 159, 1986

[4] Andrew R. Casper, “Experiential vision in El Greco's „Christ healing the blind "e", Zeitschrift für Kunstgeschichte, Berlin, pp. 349-372, 2011

[5] Max Dvorak, "The History of Art as The History of Ideas," Chen,Ping. Translate, Peking University Press. Beijing, p.123, 2010

[6] Max Dvorak, "The History of Art as The History of Ideas," Chen,Ping. Translate. Peking University Press. Beijing, p.149, 2010

[7] L.I.Kahn, "Architecture: Quiet and Light", Wang,Zhihe. Translate, Guangxi Normal University Press Group, Guilin, p.48, 2002

[8] Fu Jizhong, "Dispersion and condensation -- comparison and research of light in Greco and Rembrandt's paintings", China Academy of Art, Hangzhou, p. 15, 2016

[9] Heinrich Wolfflin, "Clasic Art", Pan,Jichang. and Chen, Ping Translate, China Renmin University Press, Beijing, p.232, 2004

[10] Max Dvorak, "The History of Art as The History of Ideas," Chen,Ping. Translate, Peking University Press. Beijing, pp.123-156, 2010 